\title{
25(OH)D was Correlated with Increased Risk of Insulin Resistance, but not mediated by Adiponectin and hsCRP
}

\author{
Anggi Kartikawati ${ }^{1,2 *}$, Yani Lina ${ }^{2,3}$, Andi Wijaya ${ }^{1,2}$ \\ ${ }^{1}$ Prodia Clinical Laboratory, Jl. Cisangkuy No.2, Bandung, Indonesia \\ ${ }^{2}$ Post Graduate Program in Clinical Biochemistry, Hasanuddin University, Jl. Perintis Kemerdekaan Km.10. Makassar, Indonesia \\ ${ }^{3}$ Prodia Stem Cell, JI. Kramat VII No. 11, Jakarta, Indonesia \\ *Correspondence: anggi.kartikawati@prodia.co.id
}

\section{Abstract}

B ACKGROUND: Studies have shown that change of calcium and vitamin D homeostasis is associated with insulin resistance, decreased beta cell function, metabolic syndrome, glucose intolerance and diabetes. Evidence suggests that vitamin D insufficiency is inversely related to risk of metabolic disorders including type-2 Diabetes Mellitus (T2DM), although the underlying mechanisms are not yet understood. Hence, current study was conducted to investigate correlation between $25(\mathrm{OH}) \mathrm{D}$ and insulin resistance through adiponectin or High Sensitivity C-Reactive Protein (hsCRP) in centrally obese men.

METHODS: This was a cross-sectional study involving 80 centrally obese men with waist circumference (WC) > $90 \mathrm{~cm}$ and age $30-60$ years. Total $25(\mathrm{OH}) \mathrm{D}$ concentration was measured by Enzyme-Linked Immunosorbent Assay (ELISA) method. Insulin resistance was calculated by HOMA model.

RESULTS: This study showed there was no correlation of 25(OH)D-WC ( $r=0.006$ and $\mathrm{p}=0.957), 25(\mathrm{OH})$ D-adiponectin $(r=0.179$ and $\mathrm{p}=0.111)$ and $25(\mathrm{OH})$ D-hsCRP $(r=-0.223$ and $p=0.334)$, but we observed

\section{Abstrak}

ATAR BELAKANG: Studi menunjukkan bahwa perubahan homeo-stasis kalsium dan vitamin D berhubungan dengan resistensi insulin, penurunan fungsi sel beta, sindrom metabolik, intoleransi glukosa dan diabetes. Studi ini bertujuan untuk mempelajari korelasi antara 25(OH)D dan resistensi insulin melalui adiponektin atau High Sensitivity C-Reactive Protein (hsCRP) pada pria obesitas sentral, yang dikarakterisasi dengan lingkar perut/waist circumference $(\mathrm{WC})>90 \mathrm{~cm}$.

METODA: Studi ini merupakan studi cross-sectional yang melibatkan 80 pria obesitas sentral dengan WC $>90$ $\mathrm{cm}$ dan berusia 30-60 tahun. Konsentrasi 25(OH)D total ditentukan dengan metoda Enzyme-Linked Immunosorbent Assay (ELISA). Resistensi insulin dihitung menggunakan perhitungan HOMA.

HASIL: Studi menunjukkan tidak ada korelasi 25(OH) $\mathrm{D}$ dengan WC $(\mathrm{r}=0,006$ dan $\mathrm{p}=0,957), 25(\mathrm{OH})$ D-adiponectin $(\mathrm{r}=0,179$ dan $\mathrm{p}=0,111)$ dan $25(\mathrm{OH})$ D-hsCRP ( $r=-0,223$ dan $p=0,334)$, akan tetapi kami menemukan korelasi negatif signifikan antara 25(OH)D dan insulin resistance index/(HOMA-IR) $(r=-0,461$ dan $\mathrm{p}=0,041)$. 
statistically significant negative correlation between 25(OH)D and insulin resistance index (HOMA-IR) $(\mathrm{r}=$ -0.461 and $\mathrm{p}=0.041$ ).

CONCLUSIONS: We conclude that low 25(OH)D concentration was significantly associated with increased risk of insulin resistance. Since the adiponectin or hsCRP was not correlated, the possible pathways need to be further investigated.

KEYWORDS: Central Obesity, 25(OH)D, Adiponectin, hsCRP, Insulin Resistance (HOMA-IR)

Indones Biomed J 2012; 4 (2): 84-92
KESIMPULAN: Studi ini menyimpulkan bahwa konsentrasi 25(OH)D yang rendah secara signifikan berhubungan dengan peningkatan risiko mengalami resistensi insulin walaupun tidak melalui jalur hsCRP maupun adiponektin. Peneliti menduga adanya jalur lain yang terlibat dalam kondisi ini seperti jalur Parathyroid Hormone (PTH) dan Free Fatty Acid (FFA), akan tetapi hal ini membutuhkan penelitian lebih lanjut.

KATA KUNCI: Central Obesity, 25(OH)D, Adiponectin, hsCRP, Insulin Resistance (HOMA-IR)

Indones Biomed J 2012; 4 (2): 84-92

\section{Introduction}

Obesity is a metabolic disease that occurs worldwide and progressively contributes to some diseases such as type 2 diabetes T2DM, hypertension, dyslipidemia and cardiovascular disease (1). Obesity is characterized by imbalance between energy intake (food consumption) and energy usage (2).

In obesity, the adipose tissue produces a variety of cytokines and hormones such as adipokines or adipocytokines and adiponectin that influence the development of T2DM and Coronary Heart Disease (CHD) (3). Adiponectin is an adipocytokine existing most abundantly in adipocyte, which concentration is decreased in obesity, T2DM and CHD. Hypoadiponectinemia is associated with low High-Density Lipoprotein (HDL) cholesterol, decreased particle size of Low-Density Lipoprotein (LDL) cholesterol and increased markers of systemic inflammation such as hsCRP. Therefore, measurement of the concentration of adiponectin can be used as an important indicator for detection of metabolic and inflammatory diseases (4).

Vitamin D is a prohormone that can be obtained from the diet, supplements, and endogenous synthesis from 7-dehydrocholesterol after skin exposure to sunlight (UV B). The endogenous synthesis produces vitamin D3 (cholecalciferol), which is transported to the liver by vitamin $\mathrm{D}$ binding protein (DBP). Vitamin $\mathrm{D}$ in food or supplements is found in the form of cholecalciferol or ergocalciferol (vitamin $\mathrm{D}_{2}$ ). Their absorption mainly occurs in the duodenum through the lymphatic system as part of chylomicrons, and is metabolized to remnant particles that transport vitamin $\mathrm{D}$ into the liver. In the liver, vitamin $\mathrm{D}$ then adds a hydroxyl group on $\mathrm{C}-25$ by monooxygenase of the family cytochrome p450 (CYP), especially CYP27A1. The enzyme 25-hydroxylase converts vitamin D to 25(OH)D. Furthermore, 25(OH)D3 or $25(\mathrm{OH}) \mathrm{D}_{2}$ are metabolized to an active form of vitamin D $\left(1,25(\mathrm{OH}) 2 \mathrm{D}_{3}\right.$ or $\left.1,25(\mathrm{OH})_{2} \mathrm{D}_{2}\right)$, known as calcitriol, through hydroxylation of C-1 by CYP27B1 (5).

Evidence suggests that $25(\mathrm{OH}) \mathrm{D}$ can not only be used as indicator of vitamin D status, but it also has a negative correlation with adiposity, glucose homeostasis, lipid profile and blood pressure. A study by Forouhi et al. .on white subjects in UK showed a significant negative correlation between serum concentrations of 25(OH)D and Homeostatic Model Assessment-Insulin Resistance (HOMA-IR) with a follow-up of 10 years (6). Evidence suggests that vitamin D insufficiency is inversely related to risk of metabolic disorders including T2DM. Although the mechanisms underlying the multiple effects of vitamin $\mathrm{D}$ are not yet understood, at least there is one factor that can affect the mechanisms, namely the expression of vitamin $\mathrm{D}$ receptor (VDR) in $>30$ tissues including the pancreatic islet cells (6). Most cells and tissues in the body have VDR which in turn stimulates the transcription of nuclear genes for a variety of cell functions. Therefore, vitamin $\mathrm{D}$ has an effect on various diseases including chronic musculoskeletal disorders, diabetes mellitus (type 1 and 2), multiple sclerosis, cardiovascular disease, osteoporosis, and cancer (of breast, prostate, and colon) (7). 
The mechanism of how vitamin D plays a role in glucose metabolism in people who have glucose intolerance is still unclear, which requires further studies (8). Although several studies have been done to investigate the status of vitamin $\mathrm{D}$ in the incidence of insulin resistance, only very limited data are available that have been obtained from studies carried out in Asia. The aim of this study was to evaluate the role of $25(\mathrm{OH}) \mathrm{D}$ concentration in insulin resistance associated with hsCRP and adiponektin concentration in centrally obese men aged 30-60 years in Indonesia, which is rich in sunlight exposure.

\section{Methods}

\section{Patients and Methods}

This study was an obeservational study with cross sectional design carried out on centrally obese male subjects aged 30-60 years. We actually had 120 participants enrolled, but only 80 men with central obesity were recruited in the study based on the following criteria: having estimated Glomerular Filtration Rate (eGFR) $<60 \mathrm{~mL} /$ minute, serum hsCRP levels $<10 \mathrm{mg} / \mathrm{L}$, having normal Parathyroid Hormone (PTH) concentration, and not consuming anti-inflammation drugs. All of the study subjects were informed about the goals of the study, signed an informed consent, and were interviewed to get their personal data such as height, weight, waist circumference (WC), blood pressure, physical activity, drugs intake, time of sun exposure, and vitamin D supplement and milk intake. All subjects fasted for 10-12 hours. Obesity was defined as the condition with WC $>90 \mathrm{~cm}$, Insulin Resistance was defined as HOMA-IR $>2$. The study protocol was approved by the Health Research Ethics Committee Faculty of Medicine Hasanuddin University Makassar (no. UH12010013).

\section{Reagents}

Venous blood specimens were drawn and the serum was immediately separated by centrifugation and stored at $-20^{\circ} \mathrm{C}$ until examined. Serum levels of $25(\mathrm{OH}) \mathrm{D}$ were measured by ELISAusing IDS (lot no. 15072). Serum levels of hsCRP were measured by immunochemiluminescence using kits from Roche (lot no. 65275301). Serum Adiponectin levels were measured by Chemiluminescent Immunometric Assay using kit from Sekisui (lot no. 816RGI)

\section{5(OH)D Assay}

The assay was done by Sandwich ELISA method based on kit insert. Absorbance of each well was measured at $450 \mathrm{~nm}$ (reference $650 \mathrm{~nm}$ ) using a microplate reader. The HOMA model was used to determine the level of Insulin Resistance and was calculated according to the equation (9):

$$
\text { Insulin Resistance }=\frac{\mathrm{FI} \times \mathrm{G}}{22,5}
$$

Where $\mathrm{FI}=$ fasting insulin $\mu \mathrm{IU} / \mathrm{mL}$ and $\mathrm{G}=$ fasting glucose $(\mathrm{mmol} / \mathrm{L})$.

\section{Statistical Analysis}

Statistical analysis was carried out with SPSS for Windows ver. 16. Univariate analysis was done to calculate mean, maximum and minimum value also Standard Deviation (SD). Pearson bivariate correlation analysis was used to analyze the correlation of all parameters with normal distribution, and Spearman was applied to all parameters with not normal distribution. Kolgomorov-Smirnov normality test was used to assess which parameters were normally distributed ( $\mathrm{p}$ value $>0.05$ ) and which were not normally distributed ( $\mathrm{p}$ value $<0.05$ ). The results were considered significant if $\mathrm{p}$ value was $\leq 0.05$.

\section{Results}

The parameters found to be of normal distribution were age $(\mathrm{p}=0.056), 25(\mathrm{OH}) \mathrm{D}(\mathrm{p}=0.200)$, PTH $(\mathrm{p}=0.200)$, total cholesterol $(p=0.200)$, HDL cholesterol $(p=0.200)$, LDL cholesterol $(\mathrm{p}=0.200)$, and creatinine $(\mathrm{p}=0.200)$. Whereas the parameters that were not normally distributed were WC, adiponectin, HOMA-IR, hsCRP, body mass index (BMI), systolic blood pressure (SBP), diastolic blood pressure (DBP), fasting glucose, fasting insulin, aspartate aminotransferase (AST), alanine aminotransferase (ALT), triglycerides, and eGFR. To normalize the not normal distribution of the latter parameters we used logarithm method and subsequently re-tested by the KolmogorovSmirnov test. By these methods, we found the parameters that remained to be of not normal distribution were WC, BMI, SBP, DBP and fasting glucose.

The non metabolic and metabolic characteristics of the study subjects are shown in Table 1 . We carried out descriptive frequencies tests to assess the concentrations 
of quartile WC in the percentile $25,50,75$ and $>75$, respectively. The result of percentile 25 (L1):WC size $<92$ $\mathrm{cm}$; of percentile 50 (L2): WC size $92-96 \mathrm{~cm}$; of percentile 75 (L3): WC size 96-103 cm; and of percentile > 75 (L4): WC size $>103 \mathrm{~cm}$. Table 2 shows the non metabolic and metabolic characteristics based on quartile of WC.

Similarly, we did descriptive frequencies tests to assess concentrations of the quartile $25(\mathrm{OH}) \mathrm{D}$ in the percentile $25,50,75$ and $>75$, respectively. The result of percentile 25 (Q1): concentration of $25(\mathrm{OH}) \mathrm{D}<36.675 \mathrm{nmol} / \mathrm{L}$; of percentile $50(\mathrm{Q} 2)$ : concentration of $25(\mathrm{OH}) \mathrm{D} 36.675$ -
$43.450 \mathrm{nmol} / \mathrm{L}$; of percentile $75(\mathrm{Q} 3)$ : the concentration of 25(OH)D $43.450-51.450 \mathrm{nmol} / \mathrm{L}$; and of percentile > 75 (Q4): the concentration of $25(\mathrm{OH}) \mathrm{D}>51.450 \mathrm{nmol} / \mathrm{L}$. The non metabolic and metabolic characteristics based on quartile of 25(OH)D are presented in Table 3.

Results of the bivariate correlation analyses of WC and $25(\mathrm{OH}) \mathrm{D}$ with the relevant parameters are presented in Table 4. Figure 1 shows that the concentration of $25(\mathrm{OH})$ $\mathrm{D}$ has a tendency to decline in WC size of $96 \mathrm{~cm}$. Figure 2 shows quartiles of age and concentration of $25(\mathrm{OH}) \mathrm{D}$ have a tendency to decline at the age of $42-49$ years.

Table 1. Non Metabolic and Metabolic Characteristics of the Study Subjects

\begin{tabular}{|c|c|c|c|c|c|}
\hline & Mean \pm SD & Median & Mode & Min & Max \\
\hline \multicolumn{6}{|l|}{ Non Metabolic } \\
\hline $\operatorname{BMI}\left(\mathrm{kg} / \mathrm{m}^{2}\right)$ & $29.01 \pm 3.23$ & 28.04 & 23.15 & 23.15 & 38.87 \\
\hline $\mathrm{SBP}(\mathrm{mmHg})$ & $127.00 \pm 1.39$ & 120.00 & 120.00 & 90.00 & 180.00 \\
\hline $\mathrm{DBP}(\mathrm{mmHg})$ & $82.38 \pm 6.41$ & 80.00 & 80.00 & 70.00 & 100.00 \\
\hline WC (cm) & $98.12 \pm 7.27$ & 96.00 & 91.00 & 90.00 & 125.00 \\
\hline Age (years) & $43.48 \pm 8.82$ & 42.00 & 31.00 & 30.00 & 60.00 \\
\hline \multicolumn{6}{|l|}{ Metabolic } \\
\hline PTH (pg/mL) & $40.83 \pm 10.28$ & 39.96 & 31.00 & 20.00 & 65.00 \\
\hline $\mathrm{FG}(\mathrm{mg} / \mathrm{dL})$ & $96.68 \pm 7.06$ & 95.00 & 93.00 & 82.00 & 117.00 \\
\hline Insulin (ulU/mL) & $16.66 \pm 7.24$ & 14.85 & 10.00 & 6.00 & 43.00 \\
\hline Adiponectin $(\mu \mathrm{g} / \mathrm{mL})$ & $3.49 \pm 1.09$ & 3.24 & 2.00 & 1.00 & 6.00 \\
\hline HOMA-IR & $2.20 \pm 0.96$ & 1.95 & 1.60 & 0.80 & 5.60 \\
\hline 25(OH)D (nmol/L) & $44.20 \pm 10.44$ & 43.45 & 35.40 & 17.20 & 69.50 \\
\hline AST (U/L) & $26.08 \pm 8.51$ & 24.00 & 23.00 & 15.00 & 66.00 \\
\hline ALT (U/L) & $39.84 \pm 18.43$ & 36.50 & 23.00 & 14.00 & 100.00 \\
\hline Cholesterol Total (mg/dL) & $213.66 \pm 41.66$ & 216.5 & 222.00 & 111.00 & 348.00 \\
\hline Cholesterol HDL (mg/dL) & $43.34 \pm 8.15$ & 43.00 & 36.00 & 28.00 & 70.00 \\
\hline Triglyceride (mg/dL) & $195.25 \pm 113.42$ & 167.00 & 104.00 & 48.00 & 635.00 \\
\hline Cholesterol LDL (mg/dL) & $135.69 \pm 33.41$ & 137.00 & 114.00 & 68.00 & 208.00 \\
\hline hsCRP (mg/L) & $2.07 \pm 1.61$ & 1.57 & 1.00 & 0.29 & 8.53 \\
\hline Creatinine (mg/dL) & $0.94 \pm 0.12$ & 0.94 & 1.00 & 1.00 & 1.00 \\
\hline eGFR (mL/mnt/1.73m²) & $90.04 \pm 14.73$ & 87.12 & 80.00 & 61.00 & 132.00 \\
\hline
\end{tabular}

Abbreviations: $\mathrm{SD}=$ Standard Deviation; $\mathrm{BMI}=$ Body Mass Index $;$ WC $=$ Waist Circumference; $\mathrm{PTH}=$ Parathyroid Hormone: FG $=$ Fasting Glucose; HOMA-IR = homeostasis model assessment - Insulin Resistance; AST = Aspartate Aminotransferase; ALT = Alanine Aminotransferase; eGFR = Estimation Glomeroulus Filtration Rate 
Table 2. Non metabolic and metabolic characteristics of the study subjects based on quartile of WC

\begin{tabular}{|c|c|c|c|c|}
\hline & $\begin{array}{c}\mathrm{L1} \\
(<92)\end{array}$ & $\begin{array}{c}\text { L2 } \\
(92-96)\end{array}$ & $\begin{array}{c}\text { L3 } \\
(96-103)\end{array}$ & $\begin{array}{c}\text { L4 } \\
(>103)\end{array}$ \\
\hline \multicolumn{5}{|l|}{ Non metabolic } \\
\hline BMI $\left(\mathrm{kg} / \mathrm{m}^{2}\right)$ & $26.99 \pm 2.17$ & $26.90 \pm 1.37$ & $28.79 \pm 1.71$ & $32.91 \pm 3.01$ \\
\hline $\mathrm{SBP}(\mathrm{mmHg})$ & $128.67 \pm 11.26$ & $125.00 \pm 11.85$ & $126.82 \pm 17.01$ & $128.10 \pm 14.70$ \\
\hline $\mathrm{DBP}(\mathrm{mmHg})$ & $82.00 \pm 5.61$ & $82.27 \pm 6.85$ & $82.27 \pm 6.12$ & $82.86 \pm 7.17$ \\
\hline WC $(\mathrm{cm})$ & $90.90 \pm 8.24$ & $93.36 \pm 1.13$ & $98.59 \pm 2.11$ & $108.00 \pm 5.72$ \\
\hline Age (years) & $42.80 \pm 9.16$ & $44.64 \pm 9.33$ & $45.23 \pm 9.22$ & $40.90 \pm 8.64$ \\
\hline \multicolumn{5}{|l|}{ Metabolic } \\
\hline PTH (pg/mL) & $37.48 \pm 8.67$ & $37.90 \pm 10.44$ & $45.67 \pm 9.65$ & $41.20 \pm 10.43$ \\
\hline $\mathrm{FG}(\mathrm{mg} / \mathrm{dL})$ & $94.80 \pm 4.38$ & $97.68 \pm 7.26$ & $98.27 \pm 7.37$ & $95.29 \pm 7.88$ \\
\hline Insulin (ulU/mL) & $13.57 \pm 4.88$ & $14.99 \pm 6.39$ & $15.93 \pm 6.14$ & $21.37 \pm 1.01$ \\
\hline Adiponectin $(\mu \mathrm{g} / \mathrm{mL})$ & $3.66 \pm 1.05$ & $3.56 \pm 1.12$ & $3.52 \pm 1.20$ & $3.28 \pm 1.01$ \\
\hline HOMA-IR & $1.81 \pm 0.59$ & $1.95 \pm 0.82$ & $2.21 \pm 0.99$ & $2.73 \pm 1.09$ \\
\hline 25(OH)D (nmol/L) & $40.86 \pm 9.72$ & $45.81 \pm 10.41$ & $44.98 \pm 10.67$ & $44.10 \pm 10.92$ \\
\hline AST (U/L) & $25.80 \pm 9.38$ & $25.64 \pm 7.20$ & $25.55 \pm 7.12$ & $27.29 \pm 10.71$ \\
\hline ALT (U/L) & $35.67 \pm 19.47$ & $37.86 \pm 17.53$ & $41.77 \pm 18.36$ & $42.86 \pm 19.19$ \\
\hline Cholesterol Total (mg/dL) & $215.47 \pm 32.26$ & $224.09 \pm 52.21$ & $210.09 \pm 40.18$ & $205.19 \pm 36.94$ \\
\hline Cholesterol HDL (mg/dL) & $43.00 \pm 8.08$ & $47.64 \pm 9.56$ & $41.64 \pm 7.65$ & $40.86 \pm 5.43$ \\
\hline Triglyceride (mg/dL) & $239.67 \pm 148.78$ & $165.00 \pm 84.68$ & $210.64 \pm 125.67$ & $179.10 \pm 90.49$ \\
\hline Cholesterol LDL (mg/dL) & $131.00 \pm 32.91$ & $145.77 \pm 35.59$ & $131.05 \pm 36.12$ & $133.33 \pm 28.15$ \\
\hline hsCRP (mg/L) & $1.57 \pm 1.46$ & $1.81 \pm 1.20$ & $1.87 \pm 1.77$ & $2.89 \pm 1.71$ \\
\hline Creatinine (mg/dL) & $0.91 \pm 0.12$ & $0.92 \pm 0.10$ & $0.97 \pm 0.14$ & $0.94 \pm 0.13$ \\
\hline eGFR (mL/mnt/1.73m²) & $93.82 \pm 14.60$ & $91.28 \pm 11.92$ & $86.24 \pm 16.32$ & $90.04 \pm 15.84$ \\
\hline
\end{tabular}

Abbreviations: $\mathrm{SD}=$ Standard Deviation; $\mathrm{BMI}=$ Body Mass Index $;$ WC $=$ Waist Circumference; $\mathrm{PTH}=$ Parathyroid Hormone; FG $=$ Fasting Glucose; HOMA-IR = homeostasis model assessment - Insulin Resistance; AST = Aspartate Aminotransferase; ALT = Alanine Aminotransferase; eGFR = Estimation Glomeroulus Filtration Rate 
Table 3. Non metabolic and metabolic characteristics based on quartile of 25(OH)D

\begin{tabular}{|c|c|c|c|c|}
\hline & $\begin{array}{c}\text { Q1 } \\
(<36,674)\end{array}$ & $\begin{array}{c}\text { Q2 } \\
(36,675-43,449)\end{array}$ & $\begin{array}{c}\text { Q3 } \\
(43,450-51,449)\end{array}$ & $\begin{array}{c}\text { L4 } \\
(>51,450)\end{array}$ \\
\hline \multicolumn{5}{|l|}{ Non metabolic } \\
\hline $\operatorname{BMI}\left(\mathrm{kg} / \mathrm{m}^{2}\right)$ & $28.86 \pm 4.11$ & $29.44 \pm 3.06$ & $27.84 \pm 1.18$ & $28.21 \pm 1.05$ \\
\hline $\mathrm{SBP}(\mathrm{mmHg})$ & $129.50 \pm 12.34$ & $128.00 \pm 11.52$ & $123.50 \pm 12.26$ & $127.00 \pm 18.67$ \\
\hline $\mathrm{DBP}(\mathrm{mmHg})$ & $82.50 \pm 5.50$ & $81.50 \pm 8.13$ & $82.00 \pm 5.23$ & $83.50 \pm 6.71$ \\
\hline WC (cm) & $97.40 \pm 8.24$ & $98.85 \pm 8.03$ & $98.30 \pm 6.99$ & $97.95 \pm 6.13$ \\
\hline Age (years) & $42.50 \pm 8.81$ & $44.05 \pm 9.16$ & $40.85 \pm 8.27$ & $46.50 \pm 8.69$ \\
\hline \multicolumn{5}{|l|}{ Metabolic } \\
\hline PTH (pg/mL) & $41.36 \pm 12.37$ & $40.70 \pm 8.21$ & $43.07 \pm 12.08$ & $38.17 \pm 7.73$ \\
\hline $\mathrm{FG}(\mathrm{mg} / \mathrm{dL})$ & $97.80 \pm 6.95$ & $94.55 \pm 7.11$ & $98.45 \pm 7.72$ & $95.90 \pm 6.19$ \\
\hline Insulin (ulU/mL) & $15.82 \pm 7.35$ & $18.24 \pm 6.76$ & $18.01 \pm 7.34$ & $14.55 \pm 7.38$ \\
\hline Adiponectin $(\mu \mathrm{g} / \mathrm{mL})$ & $3.35 \pm 1.14$ & $3.48 \pm 0.89$ & $3.41 \pm 1.12$ & $3.73 \pm 1.23$ \\
\hline HOMA-IR & $2.10 \pm 0.93$ & $2.34 \pm 0.84$ & $2.49 \pm 1.11$ & $1.87 \pm 0.91$ \\
\hline 25(OH)D (nmol/L) & $31.36 \pm 4.52$ & $40.32 \pm 1.88$ & $47.27 \pm 2.56$ & $57.86 \pm 5.19$ \\
\hline AST (U/L) & $25.45 \pm 12.07$ & $25.45 \pm 5.69$ & $26.75 \pm 8.33$ & $26.65 \pm 7.20$ \\
\hline ALT (U/L) & $35.70 \pm 18.03$ & $39.65 \pm 15.56$ & $45.20 \pm 21.88$ & $38.80 \pm 17.80$ \\
\hline Cholesterol Total (mg/dL) & $236.15 \pm 49.61$ & $209.95 \pm 35.36$ & $203.15 \pm 41.10$ & $205.40 \pm 32.99$ \\
\hline Cholesterol HDL (mg/dL) & $42.80 \pm 6.87$ & $39.55 \pm 6.20$ & $43.50 \pm 7.82$ & $47.50 \pm 9.79$ \\
\hline Triglyceride (mg/dL) & $207.25 \pm 91.58$ & $265.55 \pm 153.06$ & $171.85 \pm 100.42$ & $136.35 \pm 44.82$ \\
\hline Cholesterol LDL (mg/dL) & $153.50 \pm 31.34$ & $123.75 \pm 33.93$ & $129.00 \pm 32.00$ & $136.55 \pm 30.83$ \\
\hline hsCRP (mg/L) & $1.83 \pm 1.28$ & $1.84 \pm 1.37$ & $2.28 \pm 1.69$ & $2.33 \pm 2.02$ \\
\hline Creatinine (mg/dL) & $0.95 \pm 0.15$ & $0.95 \pm 0.11$ & $0.90 \pm 0.12$ & $0.95 \pm 0.11$ \\
\hline eGFR (mL/mnt/1.73m²) & $88.80 \pm 16.89$ & $88.70 \pm 12.39$ & $95.43 \pm 15.31$ & $87.25 \pm 13.66$ \\
\hline
\end{tabular}

Abbreviations: $\mathrm{SD}=$ Standard Deviation; $\mathrm{BMI}=$ Body Mass Index $;$ WC $=$ Waist Circumference; PTH = Parathyroid Hormone; FG = Fasting Glucose; HOMA-IR = homeostasis model assessment - Insulin Resistance; AST = Aspartate Aminotransferase; ALT = Alanine Aminotransferase; eGFR = Estimation Glomeroulus Filtration Rate 


\section{Table 4. Results of Pearson and Spearman's Correlation Analysis}

\begin{tabular}{lcc}
\hline Correlation & \multicolumn{2}{c}{$\mathbf{r}^{\text {Total }(\mathbf{n}=80)} \mathbf{p}$} \\
\hline WC vs & & \\
HOMA-IR & $0.368^{* *}$ & 0.001 \\
hsCRP & $0.249^{*}$ & 0.026 \\
Adiponectin & -0.135 & 0.232 \\
25(OH)D vs & & \\
WC & 0.006 & 0.957 \\
HOMA-IR & $-0.461^{*}$ & 0.041 \\
Adiponectin & 0.179 & 0.111 \\
\hline
\end{tabular}

Abbreviations: WC $=$ Waist Circumference; HOMA-IR $=$ homeostasis model assessment - insulin resistance; ${ }^{* *}=$ Significant correlation with confidence level $99 \%{ }^{*}{ }^{*}=$ Significant correlation with confidence level $95 \%$

\section{Discussion}

In this study we found the mean \pm SD of $25(\mathrm{OH}) \mathrm{D}$ serum level was $44.20 \pm 10.44 \mathrm{nmol} / \mathrm{L}$. This study showed that there was no statistically significant correlation between WC and 25(OH)D, but it showed a tendency to be inversely associated with $25(\mathrm{OH}) \mathrm{D}(\mathrm{r}=-0.173, \mathrm{p}=0.466)$. Based on the results of this study we concluded that the sample size was too small, in which the age of the participants was mostly in young ages, and most of the participants were still in the "early obesity" state (WC $91 \mathrm{~cm}$ and BMI $23.15 \mathrm{~kg}$ / $\mathrm{m}^{2}$ ), so their cholesterol metabolite 7-dehydrocholesterol was still sufficient to be converted to previtamin D3, which was further transformed to the 7-dehydrocholesterol photolytic conversion into previtamin D3. Skin sunlight exposure, especially that of UVB spectrum (290-320 nm) leads to 7-dehydrocholesterol photolytic conversion into previtamin D3. Previtamin D3 is rapidly transformed into vitamin D3 through isomerization process induced by thermal effects. This endogenously synthesized vitamin D3 is transported to the liver by chylomicron remnants or by $\mathrm{DBP}$, then hydroxylated to $25(\mathrm{OH}) \mathrm{D}_{3}$ and subsequently experienced hydroxylation in the kidney to produce the active form of vitamin D (10). The negative correlation between WC and 25(OH)D showed that the greater WC measurement, the lower the $25(\mathrm{OH}) \mathrm{D}$ serum concentration. This is consistent with results of other studies that stated that since $25(\mathrm{OH}) \mathrm{D}$ is a fat soluble vitamin, the $25(\mathrm{OH})$ $\mathrm{D}$ concentration in overweight and obesity condition is decreased because it is sequestered in the fat cells (11).

Figure 1 shows that serum 25(OH)D levels had a tendency to decrease at WC $96 \mathrm{~cm}$ and rised again at WC $103 \mathrm{~cm}$. We assume this phenomenon has occurred because vitamin $\mathrm{D}$ can modulate adipogenesis through vitamin D receptor (which inhibits adipogenesis through molecular components of peroxisomes proliferatoractivated receptor $\gamma$ ) (12). Therefore, we concluded that in this study adipogenesis occurred at WC of $103 \mathrm{~cm}$.

We carried out quartile assessments on WC, and the results showed that the greater the WC measurements associated with the lower adiponectin serum concentrations, the higher hsCRP serum concentration and increased HOMA index. This is consistent with the theory that increased BMI was associated with WC and the risk of insulin resistance which can increase plasma FFA concentration resulting in insulin resistance in a variety of target organs including skeletal muscle, liver, and vascular endothelial vascular cells. The underlying pathophysiological mechanism of insulin resistance, with low insulin secretion from the pancreas, is usually accompanied by systemic inflammation (8).

A study by Zhou in 2008 has suggested that vitamin D can inhibit FFA from causing insulin resistance in muscle cells. Briefly, the study suggested that vitamin D supplement can increase tyrosine phosphorylation of insulin receptor substrate (IRS)-1, decrease serine phosphorylation IRS-1 and decrease c-Jun N-terminal 
kinase (JNK) phosphorylation which can inhibit insulin receptor signaling (13). The study by Hurst in 2009 has suggested that insulin sensitivity can be improved after vitamin D supplementation (14). Therefore, in this study we have concluded that low concentration of vitamin D can cause insulin resistance through the FFA pathway.

In this study, we found that there was a negative correlation between 25(OH)D serum concentration $(51.45-69.50 \mathrm{nmol} / \mathrm{L}(\mathrm{r}=-0.461))$ and HOMA-IR. Vitamin D in endocrine system plays a role in glucose homeostasis, especially in the mechanism of insulin secretion. Vitamin D can increase the activation of protein synthesis in pancreatic beta cells, modulate the glycolytic pathway, increase calcium influx into pancreatic beta cells, and vitamin D not only facilitates the biosynthetic capacity of cells, but it also accelerates the conversion of proinsulin to insulin (15).

Vitamin D can affect insulin activity directly by stimulating the expression of insulin receptor and thereby enhance insulin responsiveness of glucose transport. Indirectly, vitamin D affects the activity of insulin through its role in the regulation of extracellular calcium and ensuring normal calcium influx through the cell membrane and the intracellular cytosolic calcium sufficient. Calcium plays an important role in insulin-mediated intracellular processes in insulin-responsive tissues such

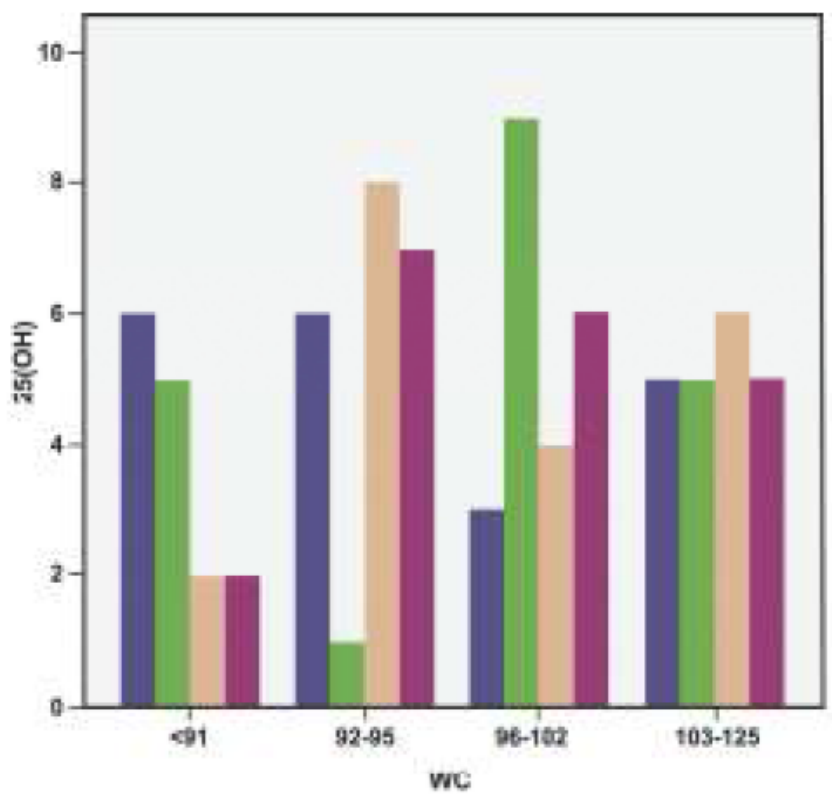

Figure 1. Tendencies of 25(OH)D and WC. as skeletal muscle and adipose tissue. Changes in calcium concentration in primary insulin target tissues may lead to insulin resistance due to impaired insulin signal transduction which causes lowered activity of glucose transporter-4 (GLUT-4) (16).

Vitamin D may improve insulin sensitivity by lowering FFA. The release of FFA from adipose tissue can induce insulin resistance, whereas 1,25-dihydroxyvitamin D has been shown to counteract the free fatty acidinduced insulin resistance (13). In this study, we suggested that significant correlation between $25(\mathrm{OH}) \mathrm{D}$ and triglyceride had occurred through FFA pathway because hipertriglyceridemia could cause increased FFA flux into the liver (17). Because 25(OH)D can decrease FFA, vitamin $\mathrm{D}$ deficiency may cause hypertriglyceridemia.

Hyperparathyroidism is a consequence of vitamin D deficiency among obese population (18), and in this study the greater WC measurements had a tendency to be accompanied with higher PTH concentrations. PTH concentrations are often elevated in vitamin D deficiency states and further confound the correlation between the concentration of $25(\mathrm{OH}) \mathrm{D}$ with insulin sensitivity. PTH can increase serine phosphorylation of IRS-1 in the adipocytes which will cause a decrease in insulin stimulation of glucose uptake (19).

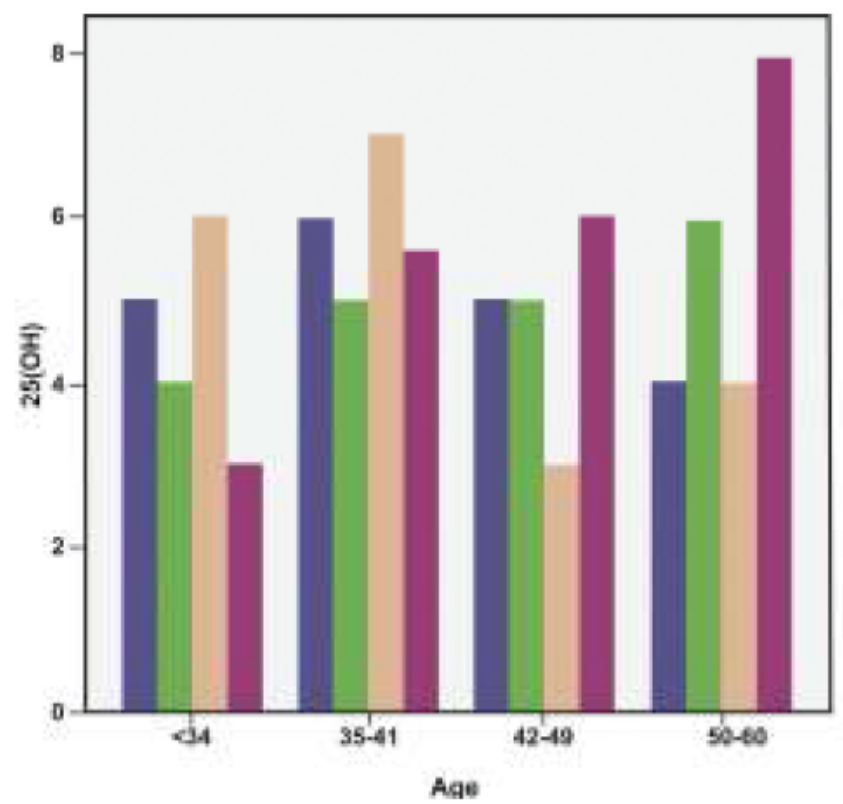

Figure 2. Tendencies of 25(OH)D and Age. 


\section{Conclusion}

According to the results of our study, we conclude that there is decrease of serum $25(\mathrm{OH}) \mathrm{D}$ levels in centrally obese men. We suggest that serum 25(OH)D concentration $>51.450 \mathrm{nmol} / \mathrm{L}$ increases insulin sensitivity in centrally obese men.

\section{Acknowledgement:}

We would like to thank the Prodia Education and Research Institute for the invaluable supports given to this study.

\section{References:}

1. James WP. The Epidemiology of Obesity: the Size of the Problem. J Intern Med. 2008; 263: 336-52.

2. Singla $P$, Bardoloi A, Parkash AA. Metabolic Effects of Obesity: A Review. World J Diabetes. 2010; 1: 76-88

3. Pischon T, Rimm EB. Adiponectin: A Promising Marker for Cardiovascular Disease. Clin Chem. 2006; 52: 797-9

4. Von Eynatten M, Hamann A, Twardella D, Nawroth PP, Brenner H, Rothenbacher. Relationship of Adiponectin' with Markers of Systemic Inflammation, Atherogenic Dyslipidemia and Heart Failure in Patients with Coronary Heart Disease. Clin Chem. 2006; 52: 853-9

5. Brannon PM, Yetley EA, Bailey RL, Picciano MF. Overview of the conference "Vitamin D and Health in the 21st Century: an Update". Am J Clin Nutr. 2008; 88: 483-90

6. Forouhi NG, Luan J, Cooper A, Boucher BJ, Wareham NJ. Baseline Serum 25-Hydroxy Vitamin D is Predictive of Future Glycemic Status and Insulin Resistance: the Medical Research Council Ely Prospective Study 19902000. Diabetes. 2008; 57: 2619-25
7. Hollis BW. Circulating 25-Hydroxyvitamin D Levels Indicative of Vitamin D Sufficiency: Implications for Establishing a New Effective Dietary Intake Recommendation for Vitamin D1. J. Nutr. 2005; 135: 317-22

8. Grimnes G, Figenschau Y,Almas B, Jorde R. Vitamin D, Insulin Secretion, Sensitivity, and Lipids. Diabetes. 2011; 60: $2748-57$

9. Matthews, Hosker JP, Rudenski AS, Naylor BA, Treacher, Turner RC. Homeostasis Model Assessment: Insulin Resistance and Beta Cell Function from Fasting Plasma Glucose and Insulin Concentration in Man. Diabetologia. 1985; 28: 412-9

10. Holick MF. Vitamin D Deficiency. N Engl J Med.2007; 357: 266-81

11. Lu L, Yu Z, Pan A, Hu FB, Franco OH, Li H, et al. Plasma 25-Hydroxyvitamin D Concentration and Metabolic Syndrome Among Middle-Aged and Elderly Chinese Individuals. Diabetes Care. 2009; 32: 1278-83

12. Wood RJ. Vitamin D and Adipogenesis: New Molecular Insights. Nutr Rev. 2008; 66: 40-6.

13. Zhou QG, Hou FF, Guo ZJ, Liang M, Wang GB, Zhang $X$. 1,25-Dihydroxyvitamin D Improved the Free Fatty-Acidinduced Insulin Resistance in Cultured C2C12 Cells. Diabetes Metab Res Rev. 2008; 24: 459-64.

14. Von Hurst PR, Stonehouse W, Coad J. Vitamin D Supplementation Reduces Insulin Resistance in South Asian Women Living in New Zealand Who are Insulin Resistant and Vitamin D Deficient - a Randomised, Placebo-Controlled Trial. Br J Nutr. 2009; 103: 549-55

15. Reis AF, Hauache OM, Velho G. Vitamin D Endocrine System and the Genetic Susceptibility to Diabetes, Obesity and Vascular Disease: a Review of Evidence. Diabetes Metab. 2005; 31: 318-25

16. Pittas A, Joseph lau, Frank BH, Hughes D. Review : The Role of Vitamin D and Calcium in Type 2 Diabetes. A Systematic Review and Meta-Analysis. Endocrinol Metab. 2007; 92: 2017-29

17. Yuan G, Al-Shali KZ, Hegele RA. Hypertriglyceridemia: its Etiology, Effects and Treatment. CMAJ. 2007; 176: 111320.

18. Davis SV. Vitamin D Deficiency and Type 2 Diabetes in African Americans: The Common Denominators. Diabetes. 2011; 24: 148-53

19. Chang E, Donkin SS, Teegarden D. Parathyroid Hormone Suppresses Insulin Signaling in Adipocytes. Mol Cell Endocrinol. 2009; 307: 77-82. 